\title{
Correction to: Church, State and Colonialism in Southeastern Congo, 1890-1962
}

Correction to:

R. A. Loffman, Church, State and Colonialism in Southeastern Congo, 1890-1962, Cambridge Imperial and Post-Colonial Studies Series, https://doi.org/10.1007/978-3-030-17380-7

Belated corrections have been made by the author to the Front Matter and Chapters 1, 2, 3 and 4. The original version of the book has been updated with these changes.

The updated version of the book can be found at https://doi.org/10.1007/978-3-030-17380-7

(C) The Author(s) 2019

R. A. Loffman, Church, State and Colonialism in Southeastern Congo, 1890-1962, Cambridge Imperial and Post-Colonial Studies Series, https://doi.org/10.1007/978-3-030-17380-7_9 